\title{
80. LEG 37 CRUISE SYNTHESIS: THE LITHOLOGY, STRUCTURE, PETROLOGY AND MAGNETIC HISTORY OF LAYER 2
}

\author{
Paul T. Robinson, James M. Hall, and the Shipboard Scientific Party ${ }^{1}$
}

\section{INTRODUCTION}

The main objective of Leg 37 was the deep penetration of the upper part of the ocean crust in order to investigate the petrological and geophysical nature of layer 2. To this end, a single deep hole was planned at Site 332 in Deep Drill Valley on the west flank of the Mid-Atlantic Ridge at about $36^{\circ} 50^{\prime} \mathrm{N}$ lat, $33^{\circ} 40^{\prime} \mathrm{W}$ long. A maximum penetration of 583 meters into acoustic basement was achieved at this site before technical problems forced the abandonment of the hole. Another deep penetration was attempted at Site 333, also in Deep Drill Valley, but this hole was terminated at a subbasement depth of 310 meters. Subsequently, two single-bit holes were drilled at Sites 334 and 335 along a sea floor spreading flow line extending from the crest of the Mid-Atlantic Ridge through Sites 332 and 333 (Figure 1).

Basement ages at the four sites range from $3.5 \mathrm{~m} . \mathrm{y}$. at Sites 332 and 333 to approximately 13 m.y. at Site 335 (Howe and Miles, Chapter 79, this volume). The sites were specifically selected to investigate secular changes in crustal material derived from a single spreading center.

Basement recovery ranged from a low of $8 \%$ at Site 333 to a maximum of $39 \%$ at Site 335 , with an overall average of about $20 \%$. Except at Site 333 and the top 200 meters of Hole 332B some material was recovered from each 9.5-meter core, hence it is unlikely that major lithologic or chemical units were missed in the sampled sections.

\section{LITHOLOGY OF LAYER 2}

Layer 2 rocks recovered on Leg 37 consist chiefly of extrusive basalt, basalt breccia, and minor nannofossil chalk and limestone. Few intrusive bodies were recognized in the drilled sections, but definitive criteria for distinguishing intrusive from extrusive rocks are

'F. Aumento, Dalhousie University, Halifax, Nova Scotia (Cochief scientist); W.G. Melson, National Museum of Natural History, Smithsonian Institution, Washington, D.C. (Co-chief scientist); H. Bougault, Centre Océanologique de Bretagne, Brest, France; L. Dmitriev, Academy of Sciences of the U.S.S.R., Moscow, U.S.S.R.; J.F. Fischer, The University of Texas at Arlington, Arlington, Texas; M. Flower, Ruhr-Universität Bochum, Bochum-Querenburg, West Germany; R.C. Howe, Indiana State University, Terre Haute, Indiana; R.D. Hyndman, Dalhousie University, Halifax, Nova Scotia; G.A. Miles, University of Oregon, Eugene, Oregon; T.L. Wright, U.S. Geological Survey, Washington, D.C. lacking and some intrusive bodies may have gone unrecognized. A plutonic complex composed of gabbro and peridotite was encountered beneath 50 meters of basalt at Site 334, but this body was probably emplaced tectonically and is not a magmatic intrusive into layer 2.

The drilled sequences were divided into major lithologic units largely on the basis of texture and phenocryst mineralogy and into subunits on the basis of cooling breaks as evidenced by glassy rinds, breccia zones, sedimentary interbeds, and highly vesicular zones. An attempt was also made to define sequences that represent eruption from a single magma source, using the following criteria:

1) Each eruptive sequence must have a unique magnetic polarity and a variation in magnetic inclinations that averages $\pm 3^{\circ}$.

2) Each sequence must have a coherent chemistry, i.e., all rocks of the sequence must have the same chemical compositions or vary in such a way that a single source can be inferred.

3) Lithologies within each sequence must be similar within the limits set by (2), i.e., variations in phenocryst content, if present, should reflect eruption from a single zoned magma chamber.

Even using the criteria outlined above, single eruptive sequences are often difficult to recognize. Where lithologic, chemical, and magnetic units coincide, eruption from a single source is highly probable. However, many sequences with uniform magnetic polarity and inclination contain basalts of variable lithology and chemistry, suggesting that multiple sources were active at the same time. Some of the lithologic and chemical variability may be due to later intrusions into the section, but such bodies would most likely have different magnetic polarities and inclinations.

The simplest layer 2 section was encountered at Site 335 where basement consists of a uniform sequence of pillow basalts with numerous glassy rinds and sedimentary interbeds. Over 130 glassy rinds were recorded from the 108-meter-thick section suggesting an average pillow thickness of less than 1 meter. Sedimentary interbeds are abundant in the upper 50 meters, but are rare in the lower half of the section. All of the recovered basalts are aphyric to sparsely phyric with 1 to 5 modal percent of phenocrysts, chiefly plagioclase, with lesser amounts of olivine and augite. Only one lithologic unit is recognized and all of the basalts have uniform magnetic polarities and inclinations suggesting a single eruptive sequence. 


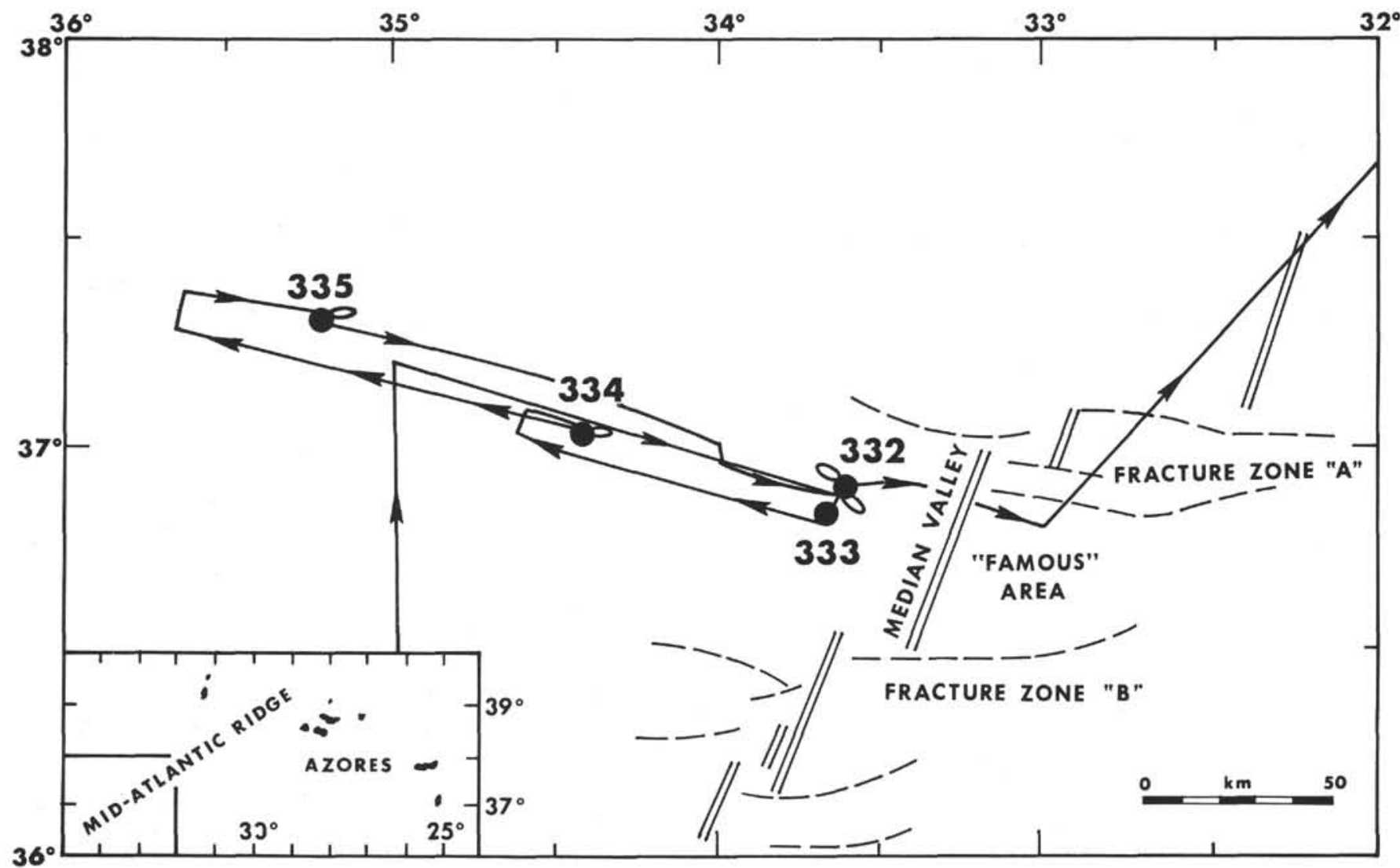

Figure 1. Location of sites drilled during Leg 37.

Fresh glass is very uniform in composition; whole rock compositions are more variable, but form a coherent group, suggesting that differences in chemistry reflect differences in phenocrystic composition. The close grouping of cleaned NRM inclinations $\left(-64^{\circ} \pm 1^{\circ}\right)$ suggests that the basalts at this site were erupted during a single secular variation cycle of the geomagnetic field representing a time span of 100 years or less.

At Site 334 approximately 50 meters of pillow basalt overlie a plutonic complex at least 67 meters thick. Two lithologic units are recognized in the basalts, a lower aphyric unit and an upper unit with $5 \%-10 \%$ of plagioclase and minor olivine and augite phenocrysts. Within the two units 14 cooling breaks can be identified based on glassy rinds and interlayered sediments. The two lithologic units are chemically similar, but are apparently not related by fractionation of the observed phenocryst assemblage because galsses of the porphyritic unit are lower in both $\mathrm{MgO}$ and $\mathrm{Al}_{2} \mathrm{O}_{3}$ than whole-rock specimens of the aphyric unit. Rocks of both units have statistically identical cleaned NRM inclinations (average $+53^{\circ} \pm 3^{\circ}$ ) suggesting a single eruptive sequence. The small scatter of NRM inclinations suggests that the entire 50 -meter sequence was erupted over an interval of not more than 100 years.

The plutonic complex at this site consists largely of very coarse grained, two-pyroxene gabbro with lesser amounts of olivine gabbro or troctolite and partially serpentinized lherzolite. Textures and mineralogies suggest a cumulate origin similar to layered basic intrusions exposed on land. Several cycles of peridotite- olivine gabbro-gabbro, reminiscent of rhythmic layering, are present, but at least some of the lithologic repetition is due to faulting. The observed textures and the evidence for inhomogeneous strain are characteristic of many Alpine-type complexes where the relationships between gabbros and peridotites are likewise complex (Helmstaedt, Chapter 59, this volume).

Numerous breccia zones are present in the complex. Some breccias are polymict, consisting of gabbro and periodotite fragments together with broken crystals of plagioclase and pyroxene set in a matrix of nannofossil chalk. Others have a matrix of comminuted material derived from the component clasts. No basalt fragments occur in the breccias and no breccias were found in the overlying basalts. The presence of the polymict breccias with a matrix of nannofossil chalk strongly suggests that the plutonic complex was exposed to the sea floor prior to eruption of the basalts. Paleomagnetic inclinations in the complex are scattered with a poorly defined average upward inclination, opposite that of the overlying basalts. Both the scatter of paleomagnetic inclinations and the observed postmagmatic fabrics indicate emplacement of the complex into layer 2 after solidification.

Little information regarding basement lithologies was gleaned from Site 333 because of very low core recovery. Only 23 meters of basalt, basalt breccia, and soft sediment were recovered from a drilled sequence 310 meters thick. Eight lithologic units were recognized, but boundaries between units are poorly defined and some sequences may have been missed entirely. Glass rinds and palagonite breccias are common in the 
upper part of the section, but disappear at greater depths. Most of the recovered basalts are sparsely to moderately phyric with phenocrysts of olivine, plagioclase, and rare augite. Primary chemical compositions are mainly obscured by extensive low temperature alteration and major eruptive sequences are difficult to recognize. Cleaned paleomagnetic inclinations are scattered but generally shallow.

The basement section penetrated at Site 332 contains the most diverse basalt lithologies and the greatest range in basalt chemistry of all Leg 37 sites. Hole 332B penetrated 583 meters of basement with an average recovery of $21 \%$ and Hole $332 \mathrm{~A}$, drilled 100 meters from Hole 332B, penetrated 330 meters of basement with approximately $10 \%$ recovery. Eleven lighologic units have been recognized in Hole 332B; seven in Hole $332 \mathrm{~A}$.

The recovered material from both holes consists largely of aphyric to coarsely porphyritic basalt with lesser amounts of basalt breccia, palagonite breccia, and nannofossil chalk. Glassy rinds and variolites are common in many units indicating pillowed sequences. Sedimentary interbeds are common to subbasement depths of about 400 meters, but are rare to absent below this level.

Many of the basalts are highly porphyritic with abundant, large phenocrysts of one or more of the following minerals: plagioclase, olivine, augite, and spinel; others range from sparsely phyric to aphyric. Most of the basalts have quench groundmass textures indicating rapid chilling probably due to extrusion onto the sea floor. A few bodies have coarser grained, subophitic textures suggestive of an intrusive origin. The presence of intrusive bodies is also suggested by downhole variations in paleomagnetic inclinations and polarities and by the intercalation of basalts of different compositions.

Single eruptive sequences are more difficult to recognize at this site than at Sites 334 and 335 . The only compelling example of a single eruptive sequence in Hole $332 \mathrm{~A}$ is represented by the material between Core 8 , Section 1, $75 \mathrm{~cm}$ to Core 12 , Section $2,88 \mathrm{~cm}$, a thilickness of 125 meters. These rocks have closely grouped magnetic inclinations and grossly similar lithologies ranging from aphyric to coarsely plagioclase-olivine-phyric basalts. Two chemical types are dominant in this sequence and they appear to be related to one another by phenocryst fractionation. Within this sequence there are a few specimens of different chemical type although the lithologies and magnetic characteristics are similar. These specimens probably represent eruptions from other contemporaneously active sources.

In Hole 332B, lithologic Unit 1 is a coarsely plagioclase-phyric basalt with a uniform magnetic polarity and inclination and a coherent chemistry, and it probably represents a single eruptive sequence. Units 2,3 , and 4 are either chemically or magnetically variable suggesting that they were formed by intercalations of more than one eruptive type. Unit 5 is a uniform glomerophyric basalt of coherent chemistry and uniform magnetic polarity and inclination repre- senting a single eruptive sequence about 30 meters thick. Below Unit 5 the section consists largely of alternations of plagioclase-phyric and olivine-phyric basalts with few large or distinctive eruptive units.

One of the major surprises resulting from drilling at Site 332 was the lack of detailed lithologic and chemical continuity between Ho les $332 \mathrm{~A}$ and $332 \mathrm{~B}$, located about 100 meters apart. The only obvious correlation between the holes is between Unit 3 of Hole 332B and Unit 6 of Hole 332A, which are similar in gross lithology, chemistry, and magnetic polarity and inclincation. In both holes a highly plgioclase-phyric unit occurs near the top of the basement sequence suggesting a good correlation. However, despite their mineralogic similarities these units have oposite magnetic polarities and some differences in bulk chemistry. At the bottom of the Hole 332A there is a distinctive basalt with about $40 \%$ plagioclase, augite, and olivine phenocrysts which was not encountered in Hole 332B. At the same level in the latter hole there is a series of olivine-phyric basalts and picrites with distinctly different mineralogies and chemistries.

This lack of correlation between two closely spaced holes suggests that: (1) eruptions onto the sea floor are very local with extrusive rocks of different ages accumulating around closely spaced vents, (2) the drilled sequences are separated by a fault that crops out between the two holes, or (3) there has been extensive postextrusion accumulation and fractionation away from the vents. Evidence for (1) and (2) has been observed in the median rift of the FAMOUS (French-American Mid-Ocean Undersea Study) area. Here olivine-phyric lavas are typically restricted to young central volcanic ridges or mounds on the floor of the median rift (Bryan et al., Chapter 53, this volume). These partly cover older, more fractionated plagioclase-phyric lavas generally erupted from vents along the flanks of the rift. Numerous faults have also been observed on the walls and floor of the median rift (Ballard et al., 1975) suggesting possible offset of the erupted sequences. These relationships combined with mechanism (3) could produce a complex stratigraphic sequence with frequent interlayering of fractionated and unfractionated basalts similar to that found at Site 332 .

Based on Leg 37 results, construction of layer 2 of the oceanic crust appears to have taken place largely by eruption of chemically and mineralogically diverse basalt lavas in the median rift. Magnetic units and superunits suggest that the sampled sections were formed by a relatively small number of eruptions or short eruptive episodes, probably not exceeding a few tens of years in length (Hall and Ryall, Chapter 16, this volume). At times lavas were supplied from a single source; at other times multiple sources may have been active. No evidence was found to prove or disprove offridge sources for the sampled rocks. However, lacking good evidence of significantly later intrusion into the volcanic pile, we suggest that all of the lavas originated in the median valley. Supporting this conclusion is the fact that basalts recovered on Leg 37 are generally lithologically and chemically similar to those dredged from the present median rift in the FAMOUS area 
about $30 \mathrm{~km}$ east of Site 332 (Bryan et al., Chapter 53, this volume).

\section{STRUCTURE OF LAYER 2}

One of the most important goals of Leg 37 was to determine directly the physical constitution and structure of layer 2. Prior to deep drilling at Site 332 our knowledge of the layer was based almost entirely on seismic refraction studies. The most generally accepted model for the layer (Hyndman, Chapter 11, this volume) has a lower interval (layer $2 \mathrm{~b}$ ) with an average $P$ wave velocity of $5.0 \pm 0.7 \mathrm{~km} / \mathrm{sec}$ and an upper interval termed $2 \mathrm{a}$, of variable thickness and velocity. Beneath Deep Drill Valley Whitmarsh (reported in Hyndman, Chapter 11, this volume) finds a 640 -meter-thick layer $2 \mathrm{a}$ with a velocity of $2.8 \mathrm{~km} / \mathrm{sec}$ overlying layer $2 \mathrm{~b}$ material with a velocity of 4.9 $\mathrm{km} / \mathrm{sec}$.

A major problem in interpreting the refraction seismology results is that fresh basalts recovered by dredging or drilling into the upper part of layer 2 have velocities of approximately $6.0 \mathrm{~km} / \mathrm{sec}$ (Christensen and Salisbury, 1975). The mean compressional velocity of Leg 37 basalts at $0.5 \mathrm{kbar}$ pressure is $5.94 \mathrm{~km} / \mathrm{sec}$, close to the average cited above. Drilling on Leg 37, particularly at Site 332 , has provided an explanation for this apparent discrepancy in laboratory and refraction seismology velocities for layer 2 and for the occurrence of a layer $2 \mathrm{a}$ in some areas. The in situ refraction velocities must represent an average for solid basalt, broken and fractured basalt, and interlayered sediment whereas laboratory velocities represent measurements on selected solid basalt samples. Layer 2 a should be, therefore, a zone in which basalt rubble and sediment are important (from $40 \%$ to $70 \%$ of the section in Hole 332B), whereas layer $2 b$ should contain a higher proportion of solid basalt.

With an average basement recovery of only $20 \%$ the validity of this model depends on the correct interpretation of the drilling log which shows bit load and rate of penetration for any given depth. On Leg 37, high core recovery was closely correlated with high bit pressure and slow penetration, suggesting the presence of massive basalts. We conclude that intervals with low recovery, rapid penetration, and low bit pressure contain a high proportion of fractured and porous basalt or sediment. Based on the drilling record the ratio of solid basalt to basalt rubble and sediment has been computed for Hole $332 \mathrm{~B}$ and the estimated velocities compared to Whitmarsh's refraction profile for Deep Drill Valley (Figure 2). The proportion of low velocity rubble and sediment decreases with depth from about $70 \%$ at the top of the basement sequence to about $25 \%$ at the bottom (583 m subbasement). Although the drilled profile shows much more detail than the broad average layering obtained from refraction seismology, there is good agreement between the two profiles in the thickness and velocity of layer $2 a$ and the velocity of layer $2 \mathrm{~b}$. Improved recovery and the logging of basement sections will provide better tests of the model presented here.

At Site 355 basement penetration was not deep enough to define a velocity-depth profile but the average computed velocity is about $4.0 \mathrm{~km} / \mathrm{sec}$. This

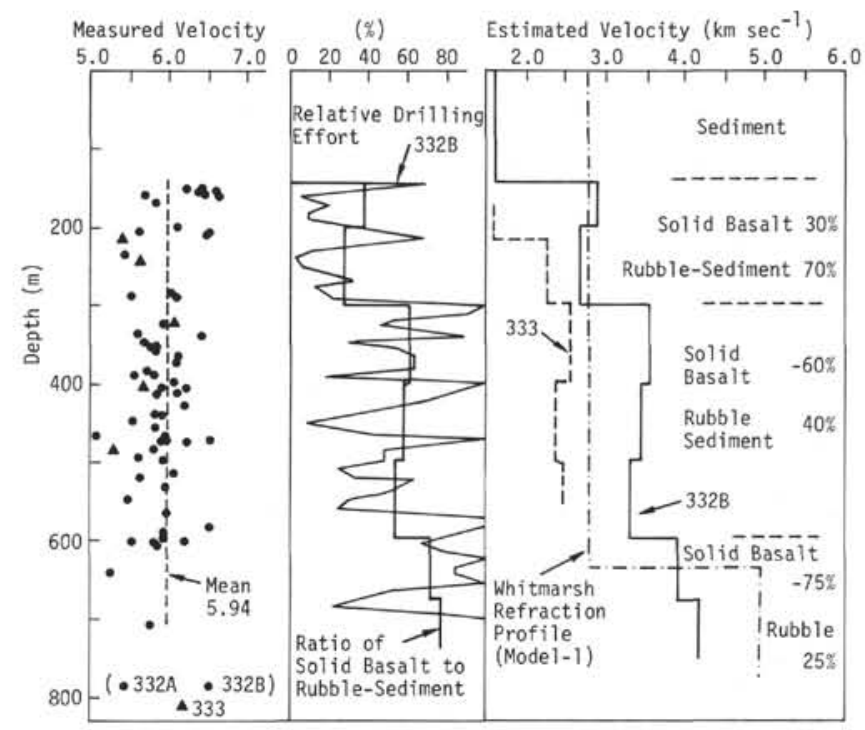

Figure 2. Measured compressional velocities at $0.5 \mathrm{kbar}$, the computed ratio of solid basalt to rubble and sediment and the inferred velocity depth profiles for Holes $332 B$ and 333A. Whitmarsh's refraction model 1 is given for comparison.

value agrees well with the layer 2 refraction velocities in the general area where the low velocity layer $2 a$ is not observed. Recovery was relatively high at this site suggesting a more solid basement section.

At Site 334 a gabbro-peridotite complex occurs in the upper part of layer 2 beneath about 50 meters of basalt. Fresh gabbros from this complex have average velocities of a little over $7 \mathrm{~km} / \mathrm{sec}$ at oceanic crustal pressures. This is close to lower layer 3 velocities derived from refraction seismology. With only $2 \%$ of water-filled voids, or other low velocity material, the velocities of the gabbros would match the average layer 3 velocity of $6.7 \mathrm{~km} / \mathrm{sec}$ (Hyndman, Chapter 11, this volume). Velocity equivalence with an upper layer 3 cumulate section is also possible (Christensen, Chapter 12 , this volume). The overall in situ velocity of the plutonic complex, which contains about $25 \%$ of serpentinized peridotite and $30 \%$ of breccia in addition to the gabbros, must be significantly less than the value obtained from fresh, unfractured gabbros alone.

Laboratory measurements of shear wave (S) velocities allow Poisson's ratio to be determined for the various layer 2 materials. This additional information, which is also obtained from refraction seismology, can help to distinguish refractors with similar P-wave velocities. For example, fractured basalts have P-wave velocities similar to the velocities of some types of sediment, but may be distinguished from the sediments by a relatively low Poisson's ratio.

Both Hyndman and Drury (Chapter 13, this volume) and Christensen (Chapter 12, this volume) give extensive data on bulk and grain density, water content, and elastic constants for Leg 37 materials and discuss the effect of these factors on seismic wave velocities.

Layer 2 rocks may also be categorized in terms of their electrical properties, and in particular, resistivity, $\rho$. This is done through natural electromagnetic 
induction with the interesting result that, to depths of a few tens of kilometers $\rho$ lies in the 1-6000 ohm meter range, lower than for most continental regions and much lower than for most dry samples of probable oceanic crust and upper mantle rocks (Cox et al., 1970). Here also, studies of Leg 37 materials have helped to reconcile the differences between laboratory and in situ measurements of $\rho$. Measurements on basalts show the importance of porosity, pore fluid, and conduction in clay minerals in sharply reducing the in situ resistivities from dry rock values. Crustal resistivity profiles based on an average value for the Leg 37 basalts of $220 \mathrm{ohm}$ meter at $23^{\circ} \mathrm{C}$, and the range of likely heat flow values, match closely values of $10-100 \mathrm{ohm}$ meter for periods of 0.5 to $2 \mathrm{hr}$ obtained in geomagnetic induction experiments (Hyndman and Drury, Chapter 13, this volume).

Other electrical property results, bearing on conductivity at high temperatures and high frequencies, conductivity mechanisms and melting and solidification behavior, are given in Katsube et al. (Chapter 15, this volume) and Schloessin and Dvorak (Chapter 14, this volume).

\section{MAGNETIC PROPERTIES OF LAYER 2}

The problem of the magnetic structure of layer 2 is discussed in Aumento et al. (Chapter 1, this volume). This is a particularly important problem since it has been widely supposed that the source of the oceanic linear magnetic anomalies lies in the upper part of layer 2. Prior to Leg 37 the most widely accepted model for the magnetic structure of layer 2 postulated a $400-500$ meter thick, intensely magnetized topmost interval, magnetic layer $2 \mathrm{a}$, which was believed to be responsible for the anomalies. Across strike, magnetic layer 2a was believed to consist of successively normally (N) and reversely (R) magnetized rectangular prisms, with alternate prisms responsible for positive and negative stripes in the magnetic anomaly pattern. In this way the polarity reversal history of the earth's magnetic field was seen to be responsible for the linear magnetic anomaly patterns of the ocean basins (Vine and Matthews, 1963).

As a result of Leg 37 the model described above is now seen as only the simplest of a wide range of possibilities. In the sense that remanent magnetization, which causes the polarity reversal history, dominates other more transient types of magnetization (induced or viscous), the Leg 37 results confirm the model of Vine and Matthews (1963). Thus, many authors (Section IV, this volume) find that in Leg 37 basalts induced and viscous magnetization, both with the direction of the present earth's field, usually account together for no more than a few percent of the in situ magnetization. However, the remanence (NRM) intensities and inclinations differ markedly from predictions of the earlier model. NRM intensity varies widely on a small scale, in response to changes in oxide grain size, degree of oxidation, and other variables, but averaged over 9.5 -meter core lengths it lies between 10 $\times 10^{-4} \mathrm{emu} / \mathrm{cm}^{3}$ and $100 \times 10^{-4} \mathrm{emu} / \mathrm{cm}^{3}$. The intensity shows no systematic variation with depth and has an overall average close to $40 \times 10^{-4} \mathrm{emu} / \mathrm{cm}^{3}$ (Hall and Ryall, Chapter 16, this volume). Two points of disagreement with the earlier model are immediately apparent: (a) average NRM intensity amounts to only $40 \%$ of the value usually assigned to magnetic layer $2 \mathrm{a}$ and (b) there is no indication of a strongly magnetized interval within layer 2 , at least to the maximum basement penetration of 583 meters. The broad distribution of NRM inclinations is also at variance with the simple model. The earlier model assumes that inclinations are close to dipole values; $+56^{\circ}$ (normal polarity) and $-56^{\circ}$ (reverse polarity) at the latitude of the Leg 37 sites. In fact, inclinations are widely distributed from $+86^{\circ}$ through the horizontal to $-73^{\circ}$, with many values from Sites 332 and 333 close to the horizontal (paleomagnetic data tables, Chapters 2, 3, 4, and 5 , this volume). The results of Leg 37 studies indicate that this wide variation in inclinations is not due to combining in various proportions stable reverse magnetization and more recently acquired soft normal magnetization, but rather is a property of the stable magnetization, which is interpreted everywhere as being aligned in the direction of the earth's magnetic field during initial cooling. The anomalous inclinations may be explained in terms of either the recording of a polarity transition of the earth's field or of post-cooling tectonic tilting. Both explanations face severe difficulties and the meaning of the anomalous inclinations remains a major problem (Hall and Ryall, Chapter 16, this volume).

In terms of accounting for linear magnetic anomaly patterns the effect of the anomalous inclinations is to reduce further the effective magnetization of the parts of layer 2 sampled on Leg 37. A number of other features work in the same way. These are the presence of a polarity reversal at 100 meters subbasement depth in Hole $332 \mathrm{~A}$, the presence of a plutonic sequence beneath a thin basalt section at Site 334, and the inferred presence of considerable amounts of effectively nonmagnetic sediment and basaltic rubble at all sites. We conclude that with the possible exception of Site 355 the sources of the linear magnetic anomalies in the Leg 37 area were not identified in the layer 2 sections examined.

Two new models for the magnetization of ocean crust can be proposed on the basis of Leg 37 results. Both have interesting petrological implications, and both can be tested by deeper drilling. In the first model magnetization at $40 \times 10^{-4} \mathrm{emu} / \mathrm{cm}^{3}$ extends to whatever depth is necessary to account for anomaly amplitudes. In general, this requires extension of the magnetized layer into seismic layer 3 . This model suggests that the magnetization resides in serpentinized peridotites, the only known suitable material in layer 3 and raises interesting questions regarding the geometrical and temporal constraints on the development of serpentinization. In the other model discrete, very strong magnetic sources are located at one or more levels within the lower two-thirds of layer 2 . Such magnetic sources in layer 2 would presumably consist of fresh basalt, carrying strong, median valley intensities of magnetization, but if so, how are such 
bodies preserved from the otherwise pervasive low temperature alteration of layer 2 ?

A number of investigators have examined the relationship between magnetic and oxide mineral properties (Dunlop and Hale, Chapter 18; Bleil and Peterson, Chapter 17; Evans and Wayman, Chapter 20; and Hall and Ryall, Chapter 23; this volume). The major controlling factor, based on the level of titanomagnetite cation deficiency appears to be the degree of low temperature oxidation. As cation deficiency increases NRM intensity, initial susceptibility, and saturation magnetization decrease whereas Curie temperature, NRM stability, and Q ratio increase.

The magnetic results from Leg 37 have important geological implications. For example, strongly episodic volcanism, with only a few tens of major eruptions accounting for most of any given layer 2 section, is implied by long intervals of uniform stable NRM inclinations, followed by a sharp change to a different inclination (Hall and Ryall, Chapter 16, this volume). Again, the problem of distinguishing extrusive and intrusive basalts can be approached by two magnetic methods, the baked rock test (Hall and Ryall, Chapter 16 , this volume) and through the degree of susceptibility anisotropy (Ellwood and Watkins, Chapter 26, this volume). Neither method, however, can produce unequivocal answers at the present time.

\section{HEAT FLOW AND HYDROTHERMAL CIRCULATION IN LAYER 2}

A major problem, outlined in Aumento et al. (Chapter 1, this volume) is reconciling observed and predicted heat flow in the vicinity of spreading ridges. It is generally agreed that the observed scattered and mostly low values are best interpreted in terms of heat loss from the newly formed crustal plate by hydrothermal circulation, that is, by convection rather than conduction. However, it is experimentally difficult to demonstrate that such convection takes place and the major contribution of Leg 37 to this problem is in providing strong circumstantial evidence that such circulation has taken place in the past and that it is continuing at the present time. This is indicated by the constancy of low heat flow values $(0.6 \pm 0.1 \mathrm{HFU})$ for three holes across Deep Drill Valley. Earlier surface probe values in the sea floor sediments of the valley are matched almost exactly by measurements in Leg 37 holes to depths of 400 meters subbasement. The considerable depth to which low heat flow occurs indicates that the circulation system responsible for the low values must be, or have been, active at basement depths of more than $\mathbf{4 0 0}$ meters. The uniformity across Deep Drill Valley requires either that circulation stopped long ago or that it presently has a very deep and regular character with a large horizontal extent (Hyndman et al., Chapter 8, this volume). Layer 3, or at least lower layer 2, are likely to be the loci of flow. The low heat flow values indicate that temperatures cannot be higher than $15^{\circ} \mathrm{C}$ at $1 \mathrm{~km}$ and $75^{\circ} \mathrm{C}$ at $5 \mathrm{~km}$ depth.

Heat flow at Site 334 (1.16 HFU) is higher than nearer the ridge crest, but is still lower than theoretical values. It is suggested that hydrothermal circulation must have been important in the vicinity of this site, but may not be active at the present time (Hyndman et al., Chapter 8 , this volume).

Still farther from the ridge axis, at Site 335, heat flow of $0.5 \mathrm{HFU}$ is again much below the theoretical value and hydrothermal circulation must still be active in the vicinity of this site. The flow of seawater down the hole into a horizon 100 meters subbasement, deduced from downhole temperature measurements, supports this interpretation. Observed surface heat flow here suggests that water at $10^{\circ} \mathrm{C}$ may be flowing at this horizon (Hyndman et al., Chapter 8, this volume).

\section{CHEMISTRY AND ORIGIN OF LEG 37 BASALTS}

Most of the basalts cored on Leg 37 lie within previously defined limits for Mid-Ocean Ridge Basalts (see Melson et al., in press; Frey et al., 1974; Kay et al., 1970). However, the variation in chemical composition, even within individual holes, is very large and the basalts range from plagioclase-phyric varieties with $\mathrm{Al}_{2} \mathrm{O}_{3}$ over 20 wt $\%$ to olivine-phyric varieties with $\mathrm{MgO}$ up to $30 \mathrm{wt} \%$.

Studies of basalt chemistry have been directed largely toward determining whether the observed chemical variations represent different primary magmas or whether they reflect various differentiation processes. Other important questions relate to the nature of the source material and the degree of partial melting required to produce the observed compositions. Also of interest is the relationship, if any, between the basalts and the plutonic complex at Site 334 .

The shipboard party approached these problems by defining basalt chemical types or groups from $\mathrm{MgO}$ variation diagrams on the basis of chemical affinity. The most important discriminants between groups are $\mathrm{Al}_{2} \mathrm{O}_{3}, \mathrm{TiO}_{2}$, and $\mathrm{FeO}$ for given $\mathrm{MgO}$ contents. Each group includes not only rocks of similar chemistry, but also those whose compositions can be related by simple addition or subtraction of observed phenocryst phases. Highly altered rocks (identified by high $\mathrm{H}_{2} \mathrm{O}$ and $\mathrm{CO}_{2}$ ) were excluded, thus each group should represent a priori an independent low pressure fractionation system. Chemical differences between groups must be explained by variable parental magma compositions or by other differentiation processes.

Basalts from Sites 334 and 335 are relatively uniform in composition through significant core thicknesses. One basalt magma group is represented at Site 335 and two at Site 334. In Hole 333A, several chemical groups are represented but recovery was so low that the relative proportions of different types is not well defined, and it is possible that some groups were not even sampled.

The greatest chemical variability occurs in Site 332 basalts. Six magma groups are recognized by us for rocks from Hole 332A and seven in Hole 332B (Flower et al., Chapter 51, this volume). In the upper parts of both holes the magma groups correspond fairly closely to lithologic units. However, in the lower parts of the section basalts of different chemistry are often intercalated within a given lithlogic unit. 
Many of the basalts from Site 332 are highly porphyritic and $\mathrm{MgO}$ variation diagrams indicate that much of the observed chemical variation can be attributed to low pressure (up to $1 \mathrm{~kb}$, equivalent to about $3 \mathrm{~km}$ depth within the crust) crystal fractionation involving the observed phenocryst phases. Figure 3 illustrates the principal kinds of chemical variations related to low pressure fractionation in these rocks. Chemical variations related to fractionation of olivine, augite, and plagioclase are clearly shown. The most common phenocryst assemblages are olivine \pm spinel, olivine + plagioclase \pm spinel, and olivine + plagioclase + clinopyroxene. Three-phase cotectic fractionation was confirmed in magma groups $332 \mathrm{~A}-2$, $-3,-5,-6$ and $332 \mathrm{~B}-2,-7$ by the occurrence of green clinopyroxene phenocrysts together with plagioclase and olivine. In general, magma compositions plot away from olivine + clinopyroxene and plagioclase + clinopyroxene low pressure cotectics.

Minor element variations within magma groups are also compatible with low pressure crystal fractionation (Flower et al., Chapter 51 and Bougault, Chapter 30, this volume). Within group decrease in $100 \times \mathrm{Mg} /(\mathrm{Mg}$ $\left.+\mathrm{Fe}^{+2}\right)$ is accompanied by either an increase in $100 \times$ $\mathrm{Cr} /(\mathrm{Cr}+\mathrm{Ni})$ if olivine is the predominant fractionating mafic phase or by constant $100 \times \mathrm{Cr} /(\mathrm{Cr}$ $+\mathrm{Ni}$ ) if clinopyroxene accompanies olivine. At Sites 332 and 333 there is also moderately good correlation between $\mathrm{Zr} / \mathrm{Y}, \mathrm{P} / \mathrm{Y}$, and $\mathrm{P} / \mathrm{Zr}$ with $\mathrm{Ce} / \mathrm{Yb}$ and LILelement abundance for equivalent values of $100 \times$ $\mathrm{Mg} /\left(\mathrm{Mg}+\mathrm{Fe}^{+2}\right)$, confirming the observed low pressure fractionation trends.

Bougault (Chapter 30, this volume), based on plots of $\mathrm{Cr}$ and $\mathrm{Ni}$ versus $\mathrm{Ti}$, finds that crystal fractionation in Leg 37 basalts involves plagioclase greater than clinopyroxene greater than olivine. Based on the trace element compositions he concludes that olivine is not as important in fractionation schemes in Leg 37 basalts as it is in basalts from the FAMOUS area.

Evidence for high pressure fractionation is more limited but a few magma groups (e.g., 332B-2 and 333A-3) could be plausibly related by such a process. High pressure fractionation of olivine tholeiite magma should involve the phases olivine + plagioclase + clinopyroxene \pm orthopyroxene (Kushiro and Thompson, 1972), perhaps resulting in cumulate bodies such as that encountered at Site 334 . Derivative magmas produced by such a process should be similar in LIL-element character to the parent material but different in $100 \times \mathrm{Cr} /(\mathrm{Cr}+\mathrm{Ni})$ and $\mathrm{Cr} / \mathrm{Mg}$ ratios. Large differences in $100 \times \mathrm{Cr} /(\mathrm{Cr}+\mathrm{Ni})$ between some Leg 37 magma groups may be due to such a process.

\section{Rare Earth and Strontium Isotopic Geochemistry}

RE patterns for Leg 37 basalts are characteristic of mid-ocean ridge basalts, exhibiting an absolute level of enrichment ranging from about 4 to $15-20$ times chondrites (Schilling, et al., Chapter 38; Puchelt et al., Chapter 37; O'nions and Pankhurst, Chapter 39; this volume). Magmas with low enrichment levels probably reflect high degrees of partial melting of parent material or, alternatively, melting of a more depleted source. Analyzed Leg 37 basalts have similar, generally
$\mathrm{V}$-shaped relative RE fractionation patterns and generally similar $(\mathrm{La} / \mathrm{Sm})$ enrichment factors. Positive Eu anomalies are reported for plagioclase-rich lavas in Holes $332 \mathrm{~A}$ and $333 \mathrm{~A}$ and one specimen has a small negative Eu anomaly (Puchelt et al., Chapter 37, this volume).

$\mathrm{Ce}_{\mathrm{N}}{ }^{\prime} \mathrm{Yb}_{\mathrm{N}}$ ratios generally range from about 0.5 to 1.5. $\mathrm{Ce} / \mathrm{Yb}$ variation can be explained in part by fractional crystallization involving clinopyroxene but must also require differential partial melting and possibly minor heterogeneity in REE distribution in the source (O'nions and Pankhurst, Chapter 39, this report).

Yamaguchi et al. (Chapter 42, this volume) and Gray et al. (Chapter 41 , this volume) conclude that magmas at Site 332 had initial ${ }^{87} \mathrm{Sr} /{ }^{86} \mathrm{Sr}$ ratios of about 0.70305 , and O'nions and Pankhurst (Chapter 39, this report) give ratios for leached samples which average 0.70298 . These values for ${ }^{87} \mathrm{Sr} /{ }^{86} \mathrm{Sr}$ are higher than for some ocean floor basalts (Hart, 1975), but similar to those for basalts from the south Reykjanes Ridge and the Kolbeinsey Ridge (O'Nions and Pankhurst, 1974). Leg 37 basalts are also relatively rich in radiogenic $\mathrm{Pb}$ (Yamaguchi et al., Chapter 42, this volume). Samples with ${ }^{87} \mathrm{Sr} /{ }^{86} \mathrm{Sr}$ ratios in excess of 0.70310 probably reflect introduction of radiogenic $\mathrm{Sr}$ by interaction with seawater. Isotope data for fresh and leached Leg 37 samples are consistent with basalt magmas at all sites being derived from isotopically homogeneous mantle material.

\section{Secular Chemical Variation in Leg 37 Lavas}

Leg 37 basalts range in age from 3.5 m.y. at Site 332 to approximately $13 \mathrm{~m} . \mathrm{y}$. at Site 335 . We find some evidence for long term secular variation in magma chemistry but simple trends are lacking. Major element variations in lavas from a given site generally exceed variations between sites and largely reflect low pressure crystal fractionation and different parent magma compositions. However, Bryan et al. (Chapter 53, this volume) find some systematic differences between basalts of the FAMOUS area (time zero) and Leg 37. Many basalt glasses from the FAMOUS area have higher $\mathrm{TiO}_{2}$ (up to 1.91 wt $\%$ ) and $\mathrm{FeO} / \mathrm{MgO}$ ratios which place them outside the range of Leg 37 lavas, and there are differences in glass compositions between various Leg 37 sites (Aumento and Kempe, this volume).

Trace element variations between Leg 37 sites are more systematic than major element variations. Basalts from Sites 334 and 335 show low $\mathrm{Zr} / \mathrm{Y}$ and high $\mathrm{P} / \mathrm{Zr}$ ratios compared to rocks from younger sites. $\mathrm{Ce} / \mathrm{Yb}$ ratios are somewhat lower at Site 335 and somewhat higher at Site 334 than at the younger sites.

Schilling et al. (Chapter 38, this volume) find systematic changes in $\mathrm{La} / \mathrm{Sm}$ enrichment factors between the different sites. The highest $(\mathrm{La} / \mathrm{Sm})$ E.F values (1.5) are found in FAMOUS rocks. A noticeable decrease occurs in the enrichment factor between the FAMOUS area and Sites 332 and 333, followed by nearly constant values between Sites 333 and 334 . Another marked decrease occurs between Sites 334 and 335. At Site 335 the $(\mathrm{La} / \mathrm{Sm})$ E.F. is approximately 0.6 , 


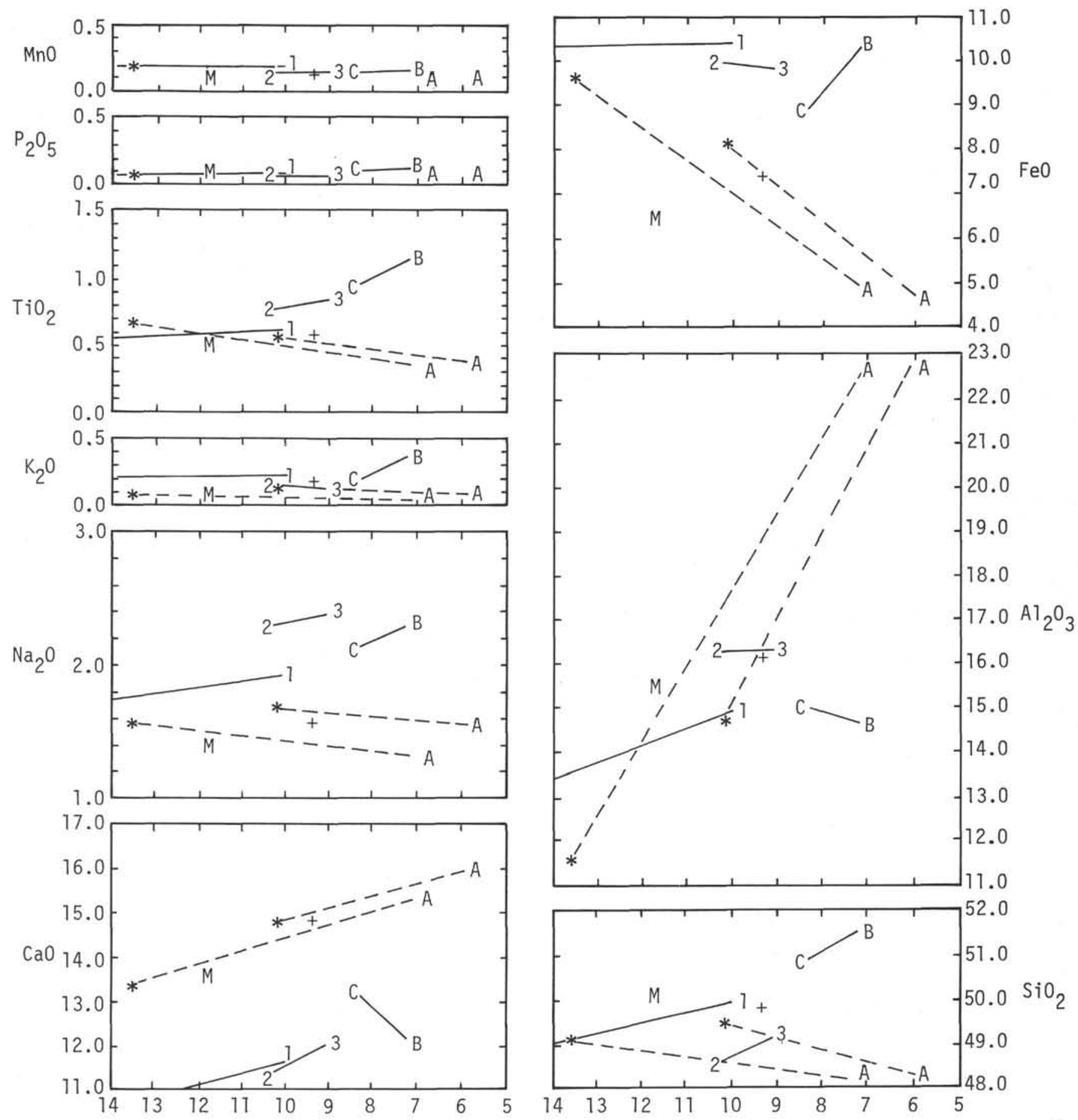

Figure 3. $\mathrm{MgO}$ variation diagrams illustrating the principal kinds of chemical variation in rocks from Leg 37. (1) Olivine $\left(F_{90}\right)$ control. The lines extending toward higher $\mathrm{MgO}$ from point "1" are olivine control lines connecting samples in Hole $332 B$, Core 35. This unit shows actual olivine accumulation. (2) Olivine $\left(F_{0}{ }_{75}\right)$ and plagioclase $\left(A n_{71}\right)$ control. Point " 2 " is a noncumulative olivine-rich basalt from Hole 332B, Core 25, Section 3, 118-120 cm. Point " 3 " is the average composition of glomerophyric lavas from Cores 22-24 in Hole 332B. Presumably the overlap in MgO between these samples and point " 1 " showing olivine fractionation only is caused by the higher $\mathrm{Al}_{2} \mathrm{O}_{3}$ content in " 2 " and " 3 " resulting in an earlier appearance of plagioclase. (3) Augite $\left(\mathrm{Ca}_{42} \mathrm{Mg}_{46} \mathrm{Fe}{ }_{2}\right)$ and plagioclase $(\mathrm{An} 75)$ control. Points " $C$ " and " $B$ " are average compositions used to define chemical groups $C$ and $B$ in Cores 8-12 of Hole 332A. The higher $\mathrm{CaO}$ content relative to $\mathrm{Al}_{2} \mathrm{O}_{3}$ content in these lavas compared to points " 2 " and "3" is presumably an important control on cyrstallization of augite instead of olivine. (4) Plagioclase (An87.5) control. Points " $A$ " represent two plagioclase-phyric lavas from Holes 332A, Core 6, Section 2, $92-94 \mathrm{~cm}$ and 332B, Core 3, Section 1. The more magnesian cumulate is from Hole 332B. The asterisks (*) represent calculated possible parent liquids related to these lavas by dashed plagioclase control lines. This assumes that only plagioclase is accumulated in these phyric lavas. The point labeled "+" is an analysis of a 
sparsely phyric lava from Hole 332B, Core 2, Section 3,31-34 cm that is closest in composition to the calculated parent liquids. The point labeled " $M$ " is a lava from Hole 332A, Core 40, in which augite, olivine, and plagioclase are also accumulated. This lava also shares some geochemical affinities (high $\mathrm{CaO}$, low $\mathrm{Na} \mathrm{O}_{2} \mathrm{O}$ ) with possible parental liquids for the plagioclase-phyric lavas.

a value typical of normal mid-ocean ridge basalts. Schilling et al. attribute the higher than normal $(\mathrm{La} / \mathrm{Sm})$ E.F to admixing of mantle material associated with the Azores mantle blob. If the spreading rate through time was constant $(1.17 \mathrm{~cm} / \mathrm{yr})$ the increase in $(\mathrm{La} / \mathrm{Sm})$ enrichment factors implies an increase in the Azores mantle blob flux. However, attempts to explain secular changes in Leg 37 lavas simply by the influence of the postulated Azores blob do comply with observed variations of all parameters, if the model is constrained by mixing of two end-members only. Moreover, the range of $\mathrm{Ce} / \mathrm{Yb}$ values at Sites 332 and 333 alone constitutes a substantial part of that attributed by Schilling et al. to mixing of disparate chemical endmembers.

\section{Alteration of Leg 37 Basalts}

Nearly all basalts recovered on Leg 37 exhibit some evidence of alteration, although in many specimens the degree of alteration is slight. Two major types of alteration are apparent (Robinson et al., Chapter 61, this volume). The most common type is a low grade pervasive alteration involving replacement of olivine and interstitial groundmass material by light brown or blue smectite. This alteration is nonoxidative in character and is spatially unrelated to fractures or open channelways. Vesicles are open or partly to completely filled with smectite and minor carbonate. The brownish to bluish smectite is a high $\mathrm{MgO}$-low $\mathrm{K}_{2} \mathrm{O}$ variety, the growth of which results in increased $\mathrm{H}_{2} \mathrm{O}^{+}$with little change in $\mathrm{K}_{2} \mathrm{O}$ contents or $\mathrm{Fe}_{2} \mathrm{O}_{3} / \mathrm{FeO}$ ratios.

The second type of alteration, often superimposed on the first, occurs in bands or halos extending outward from fractures and veinlets. The altered rocks are strongly oxidized, being various shades of yellow and red. The oxidized zones are commonly 10 to 20 times the width of the associated fracture and they are separated from unoxidized rock by sharp diffusioncontrolled fronts. Common secondary minerals in these zones are yellow or red smectite, hydrated iron oxides, carbonates and phillipsite. The yellow and red smectites are high $\mathrm{FeO}$-high $\mathrm{K}_{2} \mathrm{O}$ varieties, hence chemical changes associated with this type of alteration involve notable increases in $\mathrm{H}_{2} \mathrm{O}^{+}, \mathrm{K}_{2} \mathrm{O}$ and $\mathrm{Fe}_{2} \mathrm{O}_{3} / \mathrm{FeO}$ ratios. Magnetites in these zones of oxidation develop a wide range of cation deficiency. The peak in the distribution of cation deficiency is $0.6<z<0.8$, where $z$ is the fraction of $\mathrm{Fe}^{+2}$ oxidized to $\mathrm{Fe}^{+3}$ in the oxide (Hall and Fischer, Chapter 69, this volume).

Most of the chemical changes previously reported as a result of sea water alteration (Hart, 1969, Matthews, 1971; Melson, 1973; Thompson, 1973) involving gains in $\mathrm{Rb}, \mathrm{K}$, and $\mathrm{Ba}$ and losses in $\mathrm{Ca}, \mathrm{Mr}$, and $\mathrm{Fe}$ have been recognized in Leg 37 basalts. However, there is no overall systematic change in chemical composition with increasing alteration (Robinson et al., Chapter 61; Barager et al., Chapter 63; this volume). Instead chemical changes are strongly dependent on the nature and abundance of specific secondary minerals in the altered rocks. Nonoxidative alteration results in marked increases in water contents with little or no change in $\mathrm{K}_{2} \mathrm{O}$ or $\mathrm{Fe}_{2} \mathrm{O}_{3} / \mathrm{FeO}$ ratios. Oxidative alteration is reflected in marked increases in $\mathrm{K}_{2} \mathrm{O}, \mathrm{H}_{2} \mathrm{O}^{+}$, and $\mathrm{Fe}_{2} \mathrm{I}_{3} / \mathrm{FeO}$ ratios. Where abundant carbonate fixation has occurred (e.g., in Hole 332B) altered rocks are strongly enriched in $\mathrm{CO}_{2}$ and $\mathrm{CaO}, \mathrm{MgO}$, or $\mathrm{FeO}$ depending on which carbonate phase is present (calcite, aragonite, dolomite, or magnesite).

As expected the distribution of $\mathrm{Ti}, \mathrm{Ni}, \mathrm{Co}, \mathrm{Cu}, \mathrm{Zn}$, and $\mathrm{Sr}$ in Leg 37 basalts is little affected by alteration (Andrews et al., Chapter 62, this volume), although secondary manganese and titanium compounds are present in a few specimens (Robinson et al., Chapter 61, this volume). Mitchell and Aumento (Chapter 31, this volume) find a marked increase in $U$ rocks subjected to oxidative alteration.

All available evidence indicates that alteration of Leg 37 basalts involved low temperature interaction of seawater and basalt. No indisputable chemical or mineralogical evidence was found for hydrothermal alteration. All of the analyzed basalts have been enriched in $\mathrm{O}^{18}$ with measured values between $6 \%$ and $10 \%$ (Gray et al. Chapter 41; Muehlenbachs, Chapter 43; Hoernes and Friedrichsen, Chapter 40; this volume), indicating that cold seawater must have had access to basalt quite deep in the oceanic crust.

Rapid downhole variations in alteration type and intensity reflect different degrees of fracturing in the rock. Within the time span represented by Leg 37 sites (approximately 10 m.y.) there are no discernible increases in degree of alteration with age of the rock.

\section{ORIGIN OF THE PLUTONIC COMPLEX AT SITE 334}

The discovery of a mafic to ultramafic plutonic complex beneath 50 meters of basalt at Site 334 has raised important questions regarding the occurrence of such rocks in the ocean basins. Are these rocks exposed samples of lower oceanic crust (layer 3) or are they mantle diapirs, emplaced either in a fracture zone or in the median rift? If these are mantle-derived intrusions, are they undifferentiated mantle or are they residual solids remaining after some degree of partial fusion? Alternatively, are these rocks cumulates, and if so, what were the parent liquids and at what depth did they form? Are there any cogenetic relationships between the plutonic rocks and oceanic tholeiites?

The complex cored at Site 334 has a number of important features that bear on these questions. The complex itself consists largely of two-pyroxene gabbro 
\pm olivine and plagioclase lherzolite. Primary textures are commonly preserved and indicate a cumulate origin for these rocks and rhythmic layering has been observed in the sequence. Clarke and Loubat (Chapter 68 , this volume) postulate 9 cycles, usually beginning with peridotite and ending with olivine-poor or olivinefree gabbro. Cycles are poorly recovered or too often incomplete perhaps due to shearing within the complex as evidenced by cataclastic textures and intercalated breccia zones.

Phase chemical studies of Symes et al. and Clarke and Loubat (Chapters 67 and 68, respectively, this volume) indicate plagioclase $\left(\mathrm{An}_{75}{ }^{-} 90\right)$, olivine $\left(\mathrm{Fo}_{83}{ }^{-}{ }_{89}\right)$, orthopyroxene ( $\mathrm{WO}_{1} \mathrm{En}_{70} \mathrm{Fs}_{29}-\mathrm{Wo}_{5} \mathrm{En}_{83}$

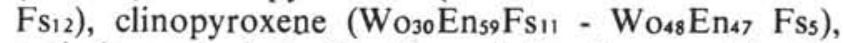
and chrome spinel. Cryptic variation is present in the upper part of the sequence and it may exist in each of the postulated cycles. Phase layering is also common with olivine and chrome spinel at the base of individual layers but absent at the top. Well-developed exsolution textures in the pyroxenes require very slow cooling at least down to $800^{\circ} \mathrm{C}$ (Hodges and Papike, Chapter 55; Hill, Chapter 60; this volume).

Although somewhat similar to the overlying basalts in major element chemistry the Site 334 gabbros are greatly depleted in LIL-elements and REE (Flower et al., Chapter 51; Bryan et al., Chapter 53; Gunn and Roobol, Chapter 58; this volume). $100 \times \mathrm{Mg} /(\mathrm{Mg}+$ $\mathrm{Fe}^{+2}$ ) values range from 69-91, the very high values being attributable to accumulation of mafic phases. The peridotites are also very depleted in REE and LILelements and have $100 \times \mathrm{Mg} /\left(\mathrm{Mg}+\mathrm{Fe}^{+2}\right)$ ratios in the range of 88-91.

One partially serpentinized peridotite yielded a ${ }^{87} \mathrm{Sr} /{ }^{86} \mathrm{Sr}$ ratio of 0.70565 (Yamaguchi et al., Chapter 42 , this volume). This high ratio, which is attributed to seawater interaction, is similar to ratios previously reported for oceanic peridotites (e.g., Melson et al., 1972).

Primary textures and mineralogies and chemical characteristics suggest that the plutonic rocks originated as a rhythmically layered cumulate complex. Rather than being the result of fractionation of a single body of magma these cumulates probably formed in a chamber that acted as a teimporary storage reservoir for magmas during their ascent to the surface (Clarke and Loubat, Chapter 68, this volume). The inferred average seismic velocity of $6.88 \mathrm{~km} / \mathrm{sec}$ (Hyndman, Chapter 11, this volume) is appropriate for layer 3 rather than mantle material.

The physical proximity of the plutonic rocks and the overlying basalts argues against a genetic relationship between the two, an interpretation supported by the differences in chemcial character. We believe that this complex was formed by fractional crystallization of primitive LIL-depleted magma in the lower crust or upper mantle and that it was later emplaced onto the floor of the median valley either by solid intrusion or tectonic uplift. The inferred average density of the complex is about $2.9 \mathrm{~g} / \mathrm{cm}^{3}$ versus an inferred value of $2.6 \mathrm{~g} / \mathrm{cm}^{3}$ for layer 2 (Hyndman et al., 1975). If these density estimates are correct, diapiric rise of the complex into layer 2 is precluded. However, core recovery in the complex was too poor to give a reliable density average, and the solid intrusion of a partially serpentinized mass is a possibility.

\section{CONCLUSIONS}

Deep drilling on Leg 37 has provided tentative answers to some major problems regarding the structure and composition of the oceanic crust. At the same time it has raised additional questions, particularly regarding the magnetic character of oceanic basalts and the origin of the linear magnetic anomalies observed on the sea floor. Many of the unanswered questions may be resolved by deeper drilling into the crust and by better core recovery in the drilled sections.

The major conclusions resulting from Leg 37 are:

1) Layer 2 of the oceanic crust consists largely of extrusive basalt with variable quantities of basalt breccia and interlayered sediment. The upper low velocity layer $2 \mathrm{a}$ is a zone with high proportions $(40 \%$ $70 \%$ ) of rubble and sediment whereas the lower layer $2 b$ consists of more massive basalt. Layer 2 stratigraphy is very complex, probably reflecting a number of overlapping and interlayered local flows of variable chemistry and mineralogy.

2) The basalts sampled on Leg 37 were erupted in the median rift of the Mid-Atlantic Ridge from 3.5 to 13 m.y.B.P. The sampled sections were formed by a relatively small number of eruptive episodes not exceeding a few tens of years in duration. The sampled basalts generally fall within previously defined limits for mid-ocean ridge tholeiites but show wide variations in chemistry and mineralogy. These compositional variations reflect extensive low pressure fractionation of plagioclase, olivine, and clinopyroxene and possibly variations in primary magma compositions. Leg 37 lavas define two major groups, one characterized by high $\mathrm{MgO}$ and total iron, the other by high $\mathrm{Al}_{2} \mathrm{O}_{3}$ and $\mathrm{CaO}$. Systematic secular variations in the compositions of Leg 37 lavas are not well defined, but there appears to be a general decrease in light REE with increasing age.

3) Leg 37 basalts have been extensively altered by low temperature-interaction with sea water. Nonoxidative alteration is the most widespread and involves the growth of blue or brown saponite and minor carbonate. Oxidative alteration occurs in halos or bands along fractures and open channelways and results in the growth of yellow or red smectite, abundant carbonate, and phillipsite. Chemical changes resulting from alteration are nonsystematic and largely reflect the presence of specific secondary minerals. There are no systematic increases in alteration either with depth in layer 2 (to a subbasement depth of $583 \mathrm{~m}$ ) or with increasing age of the crust.

4) The sampled sections do not have the necessary magnetic intensities to account for the observed linear magnetic anomalies on the sea floor. This suggests that the source of the anomalies lies deeper, either in the lower part of layer 2 or in the upper part of layer 3 . Except at Site 335, cleaned NRM inclinations of the 
basalts are much shallower than the present dipole field suggesting either post-cooling tectonic tilting or the recording of a polarity transition in the sampled sections.

5) Heat flow values in the Leg 37 area are much lower than theoritical values suggesting extensive hydrothermal circulation in the crust. The drilled sections all lack evidence of hydrothermal alteration suggesting that the areas of upwelling are small compared to the areas of sinking. The considerable depths to which low heat flow occurs indicate that the circulation system must be, or have been, active at basement depths of more 400 meters.

6) The plutonic complex encountered at Site 334 was formed by fractional crystallization of primitive LILdepleted magmas in the lower crust or upper mantle. It was emplaced onto the floor of the median valley prior to eruption of the overlying basalts either by diapiric intrusion into layer 2 or by tectonic uplift.

\section{REFERENCES}

Ballard, R.D., Bryan, W.B., Heirtzler, J.R., Keller, G., Moore, J.G., and van Andel Tj., 1975. Manned submersible observations in the FAMOUS area: MidAtlantic Ridge: Science, v. 190, p. 103-108.

Christensen, N.I. and Salisbury, M.H., 1975. Structure and constitution of the lower oceanic crust: Rev. Geophys., v. 13 , p. $57-86$.

Cox, C.S., Filloux, J.H., and Larsen, J.C., 1970. Electromagnetic studies of ocean currents and electrical conductivity below the ocean floor. In Maxwell, A.E., (Ed.), The sea, v. 4: Interscience (New York), p. 637-693.

Frey, F.A., Bryan, W.B., and Thompson, G., 1974. Atlantic Ocean floor: Geochemistry and petrology of basalts from Legs 2 and 3 of the Deep Sea Drilling Project: J. Geophys. Res., v. 79, p. 5507-5527.

Green, D.H., 1970. The origin of basaltic and nephelinitic magmas: Leicester Lit. Phil. Soc. Trans., v. 64, p. 26-54.

Hart, S.R., 1969. K, Rb, Cs contents and K/Rb, K/Cs ratios of fresh and altered submarine basalts: Earth Planet. Sci. Lett., v. 6, p. 295-303.
1976. LIL-element geochemistry, Leg 34 basalts. In Yeats, R.S., Hart, S.R., et al., Initial Report of the Deep Sea Drilling Project, Volume 34: Washington (U.S. Government Printing Office) p. 283-288.

Hyndman, R.D., Aumento, F., Melson, W.G., Hall, J.M., Bougault, H., Dmitriev, L., Fischer, J.F., Flower, M., Howe, R.C., Miles, G.A., Robinson, P.T., and Wright, T.L., 1975. Seismic structure of the oceanic crust from deep drilling on the Mid-Atlantic Ridge: Geophys. Res. Lett., v. 3, p. 201-204.

Kay, R., Hubbard, N., and Gast, P.W., 1970. Chemical characteristics and origin of oceanic ridge volcanic rocks: J. Geophys. Res., v. 75, p. 1585-1613.

Kushiro, I. and Thompson, R.N., 1972. Origin of some abyssal tholeiites from the Mid-Atlantic Ridge: Carnegie Inst. Wash. Yearbook., v. 71, p. 403-406.

Matthews, D.H., 1971. Altered basalts from Swallow Bank, an abyssal hill in the NE Atlantic; and from a nearby seamount: Phil. Trans. Roy. Soc. London, ser. A, v. 268, p. 551-571.

Melson, W.G., 1973. Basaltic glasses from the Deep Sea Drilling Project, chemical characteristics, compositions of alteration products, and fission track ages: Eos Trans. Am. Geophys. Union, v. 54, p. 1011-1014.

Melson, W.G., Hart, S.R. and Thompson, G., 1972. St. Paul's rocks, equatorial Atlantic: petrogenesis, radiometric ages, and implications on sea-floor spreading: Geol. Soc. Am. Mem. 132, p. 241-272.

Melson, W.G., Vallier, T.L., Wright, T.L., Byerly, G. and Nelen, J., in press. Jr. Geophys. Res. Monogr.

O'Nions, R.K. and Pankhurst, R.J., 1974. Petrogenetic significance of isotope and trace element variations in volcanic rocks from the Mid-Atlantic: Jr. Petrol., v. 15, p. 603-634.

Thompson, G., 1973. A geochemical study of the lowtemperature interaction of sea water and oceanic igneous rocks: Eos Trans. Am. Geophys. Union, v. 54, p. 10151018.

Vine, F.J. and Matthews, D.H., 1963. Magnetic anomalies over ocean ridges: Nature, v. 199, p. 947-949.

Wright, T.L. and Fiske, R.S., 1971. Origin of the differentiated and hybrid lavas of Kilauea Volcano, Hawaii: Jr. Petrol., v. 12, p. 1-65. 